\title{
Students' Perception Towards the Use of Moodle-Based LMS in Learning Speaking Skill at Tertiary Level
}

\author{
H. N. Truong ${ }^{1 *}$ \\ ${ }^{1}$ Van Lang University, Faculty of Foreign Languages, Ho Chi Minh City, Viet Nam. \\ *Corresponding author's email: ngoc.th@vlu.edu.vn
}

\begin{abstract}
Technology has profoundly changed how knowledge is transmitted and acquired, from exclusively classroom-based instruction to the hybrid of on-class interaction and online study. Given the prominence of blended learning in the field of language acquisition, the study aims to set the light on the students 'attitude toward the implementation of Moodle-based LMS in teaching and learning speaking skills at Van Lang University. The study employed a quantitative research method, and a questionnaire was selected as the research instrument to determine the opinions of 24 English-majored students at Van Lang University. The finding showed that most participants found the additional LMS practices useful for developing speaking skills, mainly grammatical competence, including grammar, vocabulary, and pronunciation. The recommendations on the hallmarks of desirable feedback on students' recordings may also help teachers design appropriate criteria for constructive criticism on students' spoken performance. In essence, while faceto-face interaction still remains indispensable in improving speaking skills, it should be supplemented with Moodle-based LMS practices to better acquire speaking competence.
\end{abstract}

Keywords: blended learning, Moodle-based LMS, speaking skills.

\section{INTRODUCTION}

Amid the influence of technology rippling through every facet of society, blended learning emerged as a way for education to position itself in this digital age. Traditionally, learning occurred exclusively during the on-class interaction between teachers and students. Technology came along with its power to transition learning from brick and mortar to online platforms, creating a brand-new hybrid learning mode: the combination of face-to-face and computer-assisted learning or blended learning. Since its debut, the approach has been widely embraced around the globe, especially in the field of second language acquisition.

In the context of Vietnam, blended learning has been adopted mostly by integrating the Moodle Learning Management System (LMS) course into curriculums at the tertiary level. Catching up with this trend toward digital learning, the study sets out to explore Van Lang University students' perception of Moodle-based LMS's role, particularly in teaching and learning English speaking skills, one of the core components of language acquisition. In my observation, vital as it is, oral competence is often considered the most challenging to many language learners in Van Lang University in particular and in Viet Nam as a whole. While the critical role of in-person communication is unquestionable, it is inherently difficult for English learners in EFL context to find a speaking partner, let alone the opportunities to communicate in English on regular basis. With the view to give learners more guided oral practices outside classrooms, I believe that it is time to trying our hand at blended learning as an alternative to traditional classroom-based instruction. As learners' needs and interests being the center of education, I was intrigued to find out how language learners perceived this hybrid approach and, more importantly, their view on the role of blended learning as a promising solution to enhancing their speaking skills. 


\section{LITERATURE REVIEW}

\subsection{Blended learning approach}

Blended learning is the integration of face-to-face instruction and online learning with a view to "find the most effective and efficient combination of the two modes of learning for the individual learning subjects, contexts and objectives." (p.164) [1]. The beauty of blended learning reveals itself by selecting strengths of both types of learning, [2] creating a higher level of engagement and collaboration than the traditional or virtual classroom alone [3]. In addition, when learning is transitioned to an online platform where learners can conveniently access in and outside schools, the approach contributes to expanding the learning process to take place beyond the limited space of classrooms [4]. Having the best of both instructional worlds, online and inperson, it comes as no surprise when Zhang and Zhu [5] characterized blended learning as being "accessible, flexible, active, interactive, encouraging, and inspiring" (p.26).

\subsection{The Moodle platform}

Moodle, the Modular Object-Oriented Dynamic Learning Environment abbreviations, is a free and opensource e-learning software developed by Marin Dougiamas in 2004. The logic behind this learning management system (LMS) lends itself to social constructivism principles, which puts the interactive feature of dialogues and the active role of learners at the center of second language acquisition [6]. Theoretically informed by social constructivist view, Moodle offers a wide range of multimedia tools (audio, video, image, documents) specifically catering to various educational purposes from sharing lesson-related materials, assigning and evaluating homework to reviewing on-class lessons or discussing ideas on forums.

\subsection{Research on the use of Moodle in the field of second language acquisition}

The value of Moodle in facilitating language learning and teaching has been highlighted in the research. Bataineh and Mayyas [7] looked into Moodle-based lessons' effect on developing EFL students' reading comprehension and grammar competence. The study employed a quasiexperimental design in which 32 purposefully- selected participants being randomly put into an experiment group $(\mathrm{N}=17)$ and a control group $(\mathrm{N}=15)$. Statistically, the experiment group's outperformance indicated the additional practices on Moodle contributed to developing scanning and skimming, two critical skills in reading comprehension. Similarly, they also improve grammar performance. Regarding vocabulary learning, Alavi and Keyvanshekouh [8] used MoodleReader to instill the habit of extensive reading and its effect on the acquisition of vocabulary. The data was collected through an experimental group using MoodleReader and a control group following the old way of learning reading skills. The T-test result suggested the positive effect of MoodleReader on learning vocabulary. Another feature of second language knowledge benefits from Moodlebased learning is writing skills. Theoretically informed by the hypothesis "collaborative dialogue" [9], Zeng and Takatsuka [10] designed a collaborative writing task accomplished via Moodle platform to enhance students' writing skills. The study indicated that the Moodle platform's task draws the participants' attention to the language form and fosters cooperative learning while constructing knowledge.

When it comes to speaking skills, Manan and Emzir [11] explored the Moodle-based learning model's usefulness to improve ESP students' speaking competence. The result obtained through a final speaking test showed improved students' speaking skills. Nevertheless, the discussion would be more profound if it gave insight into which aspects of speaking skills being improved with the complement of Moodle-based activities. In comparison, Rahmawati 's study [12] draw attention to the first-year students' attitude toward the use of Moodle in learning Listening and Speaking skills. A well-designed blended course draws as set up with consideration of "the learning objectives, materials, activities, educational technology tools, teacher's roles, students' roles, and assessment techniques" (p.58). The in-depth interview revealed that all the participants expressed a favorable attitude toward blended learning. Regarding speaking skills, they all agreed that speaking practices on the Moodle platform are useful in improving speaking skills and reducing their speaking anxiety. Noticeably, pronunciation, a critical dimension of spoken competence, also caught researchers' imagination in this area of study. Nhung, Oanh, Van [13] conducted experimental research to explore how effective Moodle-based task, namely recording in developing intelligible pronunciation of 62 students who were not Englishmajored. According to the result of the 12-week experiment, the experimental group made significant progress in their pronunciation. They not only made fewer mistakes, particularly in minimal pairs but also pronounce English words more confidently and accurately with self-correction, as indicated in the questionnaire and interview. 


\subsection{Literature gap}

While studies on the role of Moodle-based activities in assisting the developing language knowledge and three language skills, namely reading, writing, and listening, are extensive, only a handful of them exclusively focused on speaking skills. Perhaps, the scarcity of this research evidence reflects the widespread belief that face-to-face interaction is the best facilitating environment for oral skills to flourish. In an attempt to shed more light on the role of Moodle-based tasks in teaching and learning English speaking skills, this study dedicated itself to explore the perception of English-majored students at Van Lang University toward the use of Moodle at the practice phase of a speaking lesson. In this consideration, the research aims to answer the following questions.

\section{Research question}

1.What are the students' perceptions about the role of Moodle-based practice in improving speaking skills?

2.What are the students' suggestions on the feedbacks on the Moodle-based task?

\section{METHOD}

\subsection{Research method}

Quantitative research method was used in this study to find out the view of students on Moodle-based activities integrated into a face-to-face speaking lesson.

\subsection{Setting and participants}

The study involved 30 conveniently- selected learners who were studying in the same speaking class. The participants were freshmen at the time of the survey. Regarding English proficiency, most of them were at the pre-intermediate level, and some had great difficulty communicating their ideas in English.

\subsection{Research instruments}

The study employed a questionnaire as the main research instrument to collect quantitative data about the participants' opinions. The questionnaire was carefully designed to explore three issues related to the research concern: the participants' self-reflection on the linguistic problems which commonly stand in their way to make progress in speaking skills, their judgment on the value of the Moodle-based task to improve their speaking competence and their view on the features of desirable oral feedback.
As for the design of questionnaires, there were six questions. A Likert scale ranging from "extremely useful" to "not useful at all" was used to elicit the participants' general evaluation of the Moodle-based activity's usefulness. In addition, two five-point scales from strongly agree to strongly disagree enabled the participants to give opinions on Moodle-based activity's role in improving their vocabulary, grammar, and pronunciation: 3 important linguistic components of speaking competence. The participants selected many given options following the closed-ended format about the other two questions.

\subsection{Procedure}

The participants were fully informed about the purpose of the blended-learning course, which is dedicated to sharpening their speaking skills by combining a 3- hour classroom instruction with Moodle-based practice.

The blended- learning model for the speaking course was designed by considering these elements: the study and course objectives, the textbook, and the course assessment. For seven weeks, the on-class interaction held the main responsibility of delivering the essential vocabulary and grammar structures. The Moodle-based task played a supplemented role in giving out-of-class speaking practice. Based on the weekly topic in the textbook, relevant vocabulary and grammar structures were provided on-class instruction, while the Moodlebased activity allowed the participants to put their newlyacquired language on class into practice. The participants worked in pairs to create a dialogue based on a given situation, which varied from weeks to weeks. They uploaded the recording of their conversation on Van Lang Moodle platform after that. 


\section{FINDINGS}

Table 1: The difficulties in learning English speaking skills

\begin{tabular}{|l|c|c|}
\hline \multicolumn{1}{|c|}{$\begin{array}{c}\text { Difficulties of } \\
\text { learning English } \\
\text { speaking skills }\end{array}$} & $\begin{array}{c}\text { The } \\
\text { number of } \\
\text { response } \\
(* \mathbf{N}=\mathbf{3 0})\end{array}$ & $\begin{array}{c}\text { The } \\
\text { percentage } \\
(\%)\end{array}$ \\
\hline $\begin{array}{l}\text { Not } \\
\text { remembering } \\
\text { new words }\end{array}$ & 22 & $75 \%$ \\
\hline $\begin{array}{l}\text { Not remembering } \\
\text { new structures }\end{array}$ & 14 & $46 \%$ \\
\hline $\begin{array}{l}\text { Not having enough } \\
\text { vocabulary to express } \\
\text { ideas }\end{array}$ & 25 & $83 \%$ \\
\hline $\begin{array}{l}\text { Using grammar } \\
\text { incorrectly }\end{array}$ & 22 & $75 \%$ \\
\hline $\begin{array}{l}\text { Mispronouncing } \\
\text { English words }\end{array}$ & $23 \%$ \\
\hline
\end{tabular}

$* \mathrm{~N}$ is the number of the respondents.

Table 1 reveals the students' self-perception of speaking skills' common difficulties. Given most participants (83\%) selecting it, the lack of vocabulary was considered the biggest challenge to learning speaking skills. Ranked in the second place is the problem with English words' pronunciation with the agreement of $76 \%$ of the respondents. This is closely followed by the inability to recall newly-learned words and improper grammar. They were accounting for three-quarters. Overall, the participants might have fewer chances to use vocabulary that they learned in class outside the classroom. Otherwise, more practices would have helped them convert the declarative knowledge of vocabulary into procedural knowledge (according to the "skill acquisition theory"). [14]

Table 2: Students' perception toward the role of Moodlebased activity in improving speaking skills

\begin{tabular}{|c|c|c|}
\hline $\begin{array}{c}\text { The degree of } \\
\text { usefulness }\end{array}$ & $\begin{array}{c}\text { The number } \\
\text { of response } \\
(* \mathbf{N = 3 0})\end{array}$ & $\begin{array}{c}\text { Percentage } \\
(\%)\end{array}$ \\
\hline $\begin{array}{c}\text { Extremely } \\
\text { useful }\end{array}$ & 8 & $27 \%$ \\
\hline Very useful & 15 & $50 \%$ \\
\hline $\begin{array}{c}\text { Moderately } \\
\text { useful }\end{array}$ & 7 & $23 \%$ \\
\hline Slightly useful & 0 & $0 \%$ \\
\hline Not useful at all & 0 & $0 \%$ \\
\hline
\end{tabular}

$* \mathrm{~N}$ is the number of participants in the study.
Table 2 revealed how the participants perceive Moodlebased activity's effect on their speaking skills. Interestingly, although they all reached a consensus that the recording activity played a part, only slightly a quarter of them (27\%) viewed it extremely useful. The majority of them ranked it from moderately to very useful. In general, all participants had a favorable attitude toward the Moodle-based activity.

Table 3: Students' view on the Moodle-based activity (a recording task)

$(1=$ strongly agree $; 2=$ agree $; 3=$ neutral $; 4=$ disagree $; 5$ $=$ strongly disagree)

\begin{tabular}{|l|c|c|c|c|c|}
\hline \multirow{2}{*}{$\begin{array}{l}\text { The benefits of the } \\
\text { recording task }\end{array}$} & \multicolumn{5}{|c|}{ Percentage (\%) } \\
\cline { 2 - 6 } & $\mathbf{1}$ & $\mathbf{2}$ & $\mathbf{3}$ & $\mathbf{4}$ & $\mathbf{5}$ \\
\hline $\begin{array}{l}\text { 1-I find it a useful e- } \\
\text { learning activity } \\
\text { because I have a } \\
\text { partner to practice } \\
\text { speaking with }\end{array}$ & $19 \%$ & $81 \%$ & $0 \%$ & $0 \%$ & $0 \%$ \\
\hline $\begin{array}{l}\text { 2-I learned a lot from } \\
\text { my friend (about } \\
\text { vocabulary and } \\
\text { grammar) when we } \\
\text { were creating a } \\
\text { conversation together }\end{array}$ & $32 \%$ & $58 \%$ & $10 \%$ & $0 \%$ & $0 \%$ \\
\hline $\begin{array}{l}\text { 3-I find the task useful } \\
\text { because I can make } \\
\text { use of new words and } \\
\text { grammar structures } \\
\text { that I learned in class }\end{array}$ & $62 \%$ & $38 \%$ & $0 \%$ & $0 \%$ & $0 \%$ \\
\hline
\end{tabular}

Table 3 voices the students' opinion on the given Moodlebased activity: the recording task. Interestingly, nearly all participants $(81 \%)$ attributed the task's benefit to its interactive aspect (having a speaking partner). Besides, almost two-thirds of them found the task useful as it also gave them a chance to use previously-learned words and grammar. Despite a lower percentage of agreement $(58 \%)$, it was picking up new language knowledge from a partner worth considering as a benefit. 
Table 4: Students' view on the Moodle-based activity's role in 3 aspects of speaking skills: vocabulary, grammar, and pronunciation.

( 1 = strongly agree; $2=$ agree; $3=$ neutral $; 4=$ disagree $; 5$ $=$ strongly disagree)

\begin{tabular}{|l|c|c|c|c|c|}
\hline \multicolumn{1}{|c|}{$\begin{array}{c}\text { The benefits of } \\
\text { Moodle-based } \\
\text { activity }\end{array}$} & $\mathbf{1}$ & $\mathbf{2}$ & $\mathbf{3}$ & $\mathbf{4}$ & $\mathbf{5}$ \\
\cline { 2 - 6 } & Percentage (\%) \\
\hline $\begin{array}{l}\text { 1-I pay more } \\
\text { attention to } \\
\text { choosing better } \\
\text { words to express } \\
\text { ideas }\end{array}$ & $21 \%$ & $50 \%$ & $17 \%$ & $12 \%$ & $0 \%$ \\
\hline $\begin{array}{l}\text { 2-It helps to } \\
\text { expand my } \\
\text { vocabulary when } \\
\begin{array}{l}\text { I searched words } \\
\text { to express ideas }\end{array}\end{array}$ & $19 \%$ & $73 \%$ & $8 \%$ & $0 \%$ & $0 \%$ \\
\hline $\begin{array}{l}\text { 3-I remember } \\
\text { new words } \\
\text { acquired in class } \\
\text { longer when I use } \\
\text { them to } \\
\text { communicate } \\
\text { with my partner. }\end{array}$ & $60 \%$ & $34 \%$ & $6 \%$ & $0 \%$ & $0 \%$ \\
\hline $\begin{array}{l}\text { 4-I make fewer } \\
\text { grammar } \\
\text { mistakes when I } \\
\text { speak because I } \\
\text { usually check } \\
\text { grammar before } \\
\text { recording a } \\
\text { conversation. }\end{array}$ & $29 \%$ & $54 \%$ & $0 \%$ & $13 \%$ & $4 \%$ \\
\hline $\begin{array}{l}\text { 5-I remember } \\
\text { new structures } \\
\text { acquired in class } \\
\text { longer because I } \\
\text { used them to } \\
\text { create a } \\
\text { conversation with } \\
\text { my partner. }\end{array}$ & $63 \%$ & $25 \%$ & $4 \%$ & $8 \%$ & $0 \%$ \\
\hline $\begin{array}{l}\text { 6-I pay more } \\
\text { attention to } \\
\text { pronunciation } \\
\text { when I have to } \\
\text { record my talk. }\end{array}$ & $75 \%$ & $25 \%$ & $0 \%$ & $0 \%$ & $0 \%$ \\
\hline
\end{tabular}

Table 4 gives insight into the positive effects the Moodlebased activity has on speaking skills. Noticeably, with $75 \%$ of the participants agreed that the task put pronunciation at their attention, the potential to improve learners' pronunciation seems to be the most significant benefit of this Moodle-based activity. Additionally, better retention of newly-acquired structures and vocabulary in class also received high consensus among the participants with $63 \%$ and $60 \%$, respectively. Another noticeable response is related to the opportunity to learn new words, with the overwhelming majority of the participants $(72 \%)$ supporting it. About half of the participants claimed that they were more selective in word choice and made fewer grammar mistakes. On reflection, it seems that the three main components of speaking competence, namely vocabulary, grammar, and pronunciation, all benefit from practices on the Moodle platform.

Table 5: Suggestions on the feedback givers

\begin{tabular}{|l|c|c|}
\hline Feedback givers & $\begin{array}{c}\text { The } \\
\text { number of } \\
\text { response } \\
(* \mathbf{N}=\mathbf{3 0})\end{array}$ & Percentage (\%) \\
\hline Only a teacher & 8 & $26 \%$ \\
\hline Only classmates & 0 & $0 \%$ \\
\hline $\begin{array}{l}\text { Both teachers and } \\
\text { classmates }\end{array}$ & 22 & $73 \%$ \\
\hline
\end{tabular}

$* \mathrm{~N}$ is the number of the respondents.

Table 5 indicates the desirable commentators who evaluate the Moodle platform's oral performance. The majority of the participants $(73 \%)$ expressed a preference for both teachers and their peers playing a role as the evaluator. In contrast, peer feedback alone is totally undesirable with no one opting for it.

Table 6: Students' opinion on the aspects of language they want to receive in a feedback

\begin{tabular}{|l|c|c|}
\hline $\begin{array}{c}\text { Difficulties of } \\
\text { learning English } \\
\text { speaking skills }\end{array}$ & $\begin{array}{c}\text { The number of } \\
\text { response } \\
(* \mathbf{N}=\mathbf{3 0})\end{array}$ & $\begin{array}{c}\text { Percentage } \\
(\boldsymbol{\%})\end{array}$ \\
\hline $\begin{array}{l}\text { The accuracy of } \\
\text { vocabulary use }\end{array}$ & 30 & $100 \%$ \\
\hline $\begin{array}{l}\text { The accuracy of } \\
\text { grammar use }\end{array}$ & 30 & $100 \%$ \\
\hline Pronunciation & 17 & $56 \%$ \\
\hline $\begin{array}{l}\text { The organization of } \\
\text { ideas (how ideas } \\
\text { are organized and } \\
\text { supported) }\end{array}$ & $13 \%$ \\
\hline
\end{tabular}

$* \mathrm{~N}$ is the number of participants. 
Table 6 shows the aspects of language the students want to receive comments on. Noticeably, all of the participants expressed a total agreement that feedback should clarify whether vocabulary and grammar are used accurately or not. Although pronunciation and idea organization received lower preference, they are still supported by over half of the students. Drawn on these figures, students probably are in great need of reliable comments on their use of vocabulary and grammar.

\section{DISCUSSION}

The study is primarily set out to explore the students' view on the role of Moodle-based practice in improving speaking skills. Additionally, attention was paid to the language being perceived as the indispensable feature of feedback on spoken performance.

Regarding the first area of concern, the results show that nearly two-thirds of the participants expressed a favorable attitude toward the usefulness of Moodle-based practice on learning speaking skills. A closer look at the Moodle-based task, namely recording a dialogue, further reveals why the participants were in favor of it. Firstly, this task gave them a chance to meaningfully use words and grammar learned during on- class instruction, which presumably led to better retention of these linguistic components, as stated by over half of the participants. This benefit of "prolonged and repeated practices" theoretically lends itself to the " skill acquisition theory" [15], which emphasizes the role of " prolonged and repeated practices" in the restructuring of new knowledge, gradually resulting in the automatic use of new knowledge [16]. In light of this, Moodle-based practice could help language learners better recall new words, one of the main concerns about speaking skills.

Secondly, the students gave credit for this task to stimulate them to learn new words and select vocabulary more purposefully while creating a conversation with partners. Finally, it is worth noticing that the recording task itself helps bring pronunciation to the students' attention. In the light of "Noticing Hypothesis" [17], this conscious awareness of word choice and pronunciation is crucial for acquiring a second language. As mispronunciation is viewed as the main obstacle to develop speaking skills, this positive role of Moodlebased task enhances its value in the eye of both teachers and language learners.

Turning to the second interest in the students' view on a desirable feedback, the findings indicate that most participants prefer comments from both teachers and their peers to the one from either one of them. More importantly, the commentary on a recorded dialogue should touch on the accuracy of vocabulary and grammar use, while the feedback on how intelligible their pronunciation is and how well the ideas are organized was considered less important.

This study's results were aligned with the previous research on the same area of interest, including Manan and Emzir [11] and Rahmawati [12]. They found that students supported the blend of Moodle-based learning with in-class instruction, and further practices on Moodle platform facilitated the improvement of speaking skills. Furthermore, the usefulness of recording, a Moodlebased task in improving pronunciation, was confirmed by the study of Nhung, Oanh, and Van [13], which experimentally found a positive correlation between them.

\section{CONCLUSION}

Driven by the desire to understand the language learners' thoughts on Moodle-based learning, the study serves as a platform for the students at the English Faculty of Van lang University to voice their opinions about this area of interest. Despite the limited number of participants, the findings reflect a positive attitude toward this form of blended learning. In addition, Moodle-based learning is highly valued for its contribution to improving the students' speaking skills. This positive result could motivate an experimental research design to confirm the correlation between recording, a Moodle-based task, and speaking skill improvement. Finally, EFL teachers searching for the characteristic of desirable feedback on spoken performance might be interested in the participants' view on this concern. Given the limitation of this study, providing a groundbreaking finding in second language acquisition certainly goes far beyond what the research can offer. Hopefully, its results will contribute to the teaching and learning of speaking skills within the framework of blended learning.

\section{ACKNOWLEDGMENTS}

This work is supported by the Faculty of Foreign Languages at Van Lang University. 


\section{REFERENCES}

[1] Neumeier, P. A closer look at blended learningparameters for designing a blended learning environment for language teaching and learning. ReCALL: The Journal of EUROCALL, 17(2), 2005, p.163.

[2] Garrison, D Randy, and Norman D Vaughan. Blended Learning in Higher Education Framework, Principles, and Guidelines. John Wiley \& Sons, 2008.

[3] Tayebinik, M, and M Puteh. Blended Learning or E-Learning? International Magazine on Advances in Computer Science and Telecommunications, 3 (1), 2012, pp. 103-110.

[4] Seffner, Diane, and Leslie G Kepler. Blended Learning That Works. Vol. 32: American Society for Training and Development, 2015.

[5] Zhang, Wei, and Chang Zhu. "Comparing Learning Outcomes of Blended Learning and Traditional Face-to-Face Learning of University Students in Esl Courses." International Journal on E-Learning 17, no. 2, 2018, pp. 251-273.

[6] Vygotsky, Lev S. Mind in Society (M. Cole, V. JohnSteiner, S. Scribner, \& E. Souberman, Eds.) Cambridge, MA: Harvard University Press, 1978.

[7] Bataineh, R. F., \& Mayyas, M. B. The utility of blended learning in EFL reading and grammar: A case for Moodle. Teaching English with Technology, 17(3), 2017, pp.35-49,

[8] Alavi, S., \& Keyvanshekouh, A. Using the MoodleReader as an Extensive Reading Tool and Its Effect on Iranian EFL Students' Incidental Vocabulary Learning. English Language Teaching, 5(6), 2012, pp.135-145.
[9] Swain, Merrill. "The Output Hypothesis and Beyond: Mediating Acquisition through Collaborative Dialogue." Sociocultural theory and second language learning 97, 114, 2000

[10] Zhang, Wei, and Chang Zhu. "Comparing Learning Outcomes of Blended Learning and Traditional Face-to-Face Learning of University Students in Esl Courses." International Journal on E-Learning 17, no. 2 , pp. 251-73, 2018

[11] Manan, Nanan Abdul, and Aceng Rahmat Emzir. "Moodle-Based Speaking Learning Model." Paper presented at the Journal of Physics: Conference Series, 2020.

[12] Rahmawati, Fitria. "Blended Learning in an English Listening and Speaking Course: Freshmen's Voice and Choice." Paper presented at the Third International Conference on Sustainable Innovation 2019-Humanity, Education and Social Sciences (IcoSIHESS 2019), 2019.

[13] Nhung, N.T.Y, D.T.K Oanh, and L.H..H Van. Improving Pronunciation of Freshmen through Moodle-Based Activities, 2020

[14] Klein, Wolfgang, Wolfgang Wassilios Klein, and Klien Wolfgang. Second Language Acquisition. Cambridge University Press, 1986.

[15] DeKeyser, Robert. "Skill Acquisition Theory." Theories in second language acquisition: An introduction 97113, 2007.

[16] Ortega, Lourdes. Second Language Acquisition. Routledge London, 2011.

[17] Schmidt, Richard, and Sylvia Frota. "Developing Basic Conversational Ability in a Second Language: A Case Study of an Adult Learner of Portuguese." Talking to learn: Conversation in second language acquisition, 1986, pp. 237 -326. 